\title{
ANÁLISE DA VARIAÇÃO DA TEMPERATURA NA RESERVA PARTICULAR DO PATRIMÔNIO NATURAL, POUSADA DAS ARARAS, EM SERRANÓPOLIS-GO: UMA ABORDAGEM TOPOCLIMÁTICA
}

\author{
Regina Maria Lopes ${ }^{1}$ \\ Zilda de Fátima Mariano \\ João Batista Pereira Cabral ${ }^{3}$ \\ Alécio Perini Martins ${ }^{4}$
}

\begin{abstract}
Resumo: $O$ presente artigo teve por objetivo analisar a variação climática na escala topoclimática, utilizando dados de temperatura do ar, no período de abril de 2010 a março de 2011, na Reserva Particular do Patrimônio Natural-RPPN, Pousada das Araras-GO. Para analisar o gradiente térmico foi traçado um perfil topográfico, utilizando dados de temperatura do ar de cinco termohigrômetros, localizados ao longo da trilha da Pousada das Araras, em cotas altimétricas entre $543 \mathrm{~m}$ (cota inferior) a $619 \mathrm{~m}$ (cota superior). De acordo com os dados analisados nos horários das 15 e $21 \mathrm{~h}$ a variação da temperatura média oscilou entre 19,7 a 25,6C. Verificou-se que às $15 \mathrm{~h}$ que a correlação foi acima dos $80 \%$ e às $21 \mathrm{~h}$ constatou-se que ocorreu a inversão térmica entre os pontos P1 e P5.
\end{abstract}

Palavras-chave: temperatura do ar, topoclima, vegetação, perfil.

\section{Analysis of temperature variation in the reserva particular do patrimônio natural, Pousada das} Araras, Serranópolis-GO: a topoclimática approach

\begin{abstract}
This article was intended to analyze the climate variation on the scale topoclimática, using data from air temperature, in the period April 2010 to March 2011, in RPPN-Pousada das Araras-GO. To analyze the thermal gradient stroke was a topographical profile, using data from air temperature of five termohigrômetros, located along the trail of Pousada das Araras, under quotas altimetric data between $543 \mathrm{~m}$ (lower quota) to $619 \mathrm{~m}$ (upper bound). According to data analyzed in the schedules of 15 and 9:0 pm the variation of average temperature fluctuated between 19.7 the $25.6^{\circ} \mathrm{c}$. It was found at 3:0 pm that the correlation was over 80 and 9:0 pm it was found that the inversion occurred between points $P 1$ and $P 5$.
\end{abstract}

Key words: air temperature, topoclima, microclimate and vegetation.

\section{INTRODUÇÃO}

A Reserva Particular do Patrimônio Natural (RPPN) Pousada das Araras, no município de Serranópolis-GO foi fundada em 1996 por meio de uma parceria entre a Universidade Católica de Goiás e os proprietários da Fazenda Pedraria, Sra Ivana de Souza Braga Ramos e Sr. Marcos Ramos

\footnotetext{
${ }^{1}$ Professora Substituta da UFG, Mestre em Geografia pela UFG - Campus Jataí, doutorando Geografia UFGD

${ }^{2}$ Professora do curso e programa de mestrado em Geografia da UFG - Campus Jataí.

${ }^{3}$ Professor do curso e programa de mestrado em Geografia da UFG - Campus Jataí.

${ }^{4}$ Professor do curso de Geografia da UFG - Campus Jataí. Doutorando em Geografia - UFU
} 
da Silva. Recebeu o título de Reserva Particular do Patrimônio Natural (RPPN) em 24 de dezembro de 1998, pela da Portaria, N 173/IBAMA, tornando-se, assim, Patrimônio Histórico Brasileiro.

A Reserva apresenta um sítio arqueológico com pinturas rupestres, bem como um Cerrado stricto sensu, rico em plantas frutíferas e medicinais, tais características contribuíram para que o local se transformasse em um atrativo turístico ambiental.

Algumas pesquisas foram desenvolvidas na Reserva, em 1999, a Funatura realizou o plano de manejo para a Reserva Pousada das Araras; em 2002, Zortéa realizou um levantamento das espécies de morcegos em áreas de Cerrado; Souza (2005) pesquisou sobre o desgaste da pintura rupestre e dos abrigos na reserva; e Souza em 2009, enfocou a vegetação florística e comunidades vegetais, mostrando a alta diversidade nas espécies estudadas.

Neste sentido, a inexistência de estudos na Pousada das Araras sobre caracterização microclimática, envolvendo, principalmente, registros como temperatura do ar, umidade relativa do ar e precipitação pluvial, levou a realização dessa pesquisa.

As pesquisas sobre análise topoclimática e microclimática, em diferentes ambientes, demonstram a importância de compreender os elementos climáticos, como temperatura e umidade relativa do ar, radiação solar, vento e evapotranspiração, entre outros fatores que contribuem para o planejamento climático e ambiental de uma determinada área.

Este trabalho analisou as características da variação da temperatura do ar, considerando o topoclima na área de abrangência da Pousada das Araras e os demais fatores geográficos, como relevo, solo, geologia, vegetação e outros, dentro da dinâmica do ambiente.

O objetivo geral foi analisar a variação climática na escala topoclimática, utilizando dados de temperatura do ar no período de maio de 2010 a março de 2011.

\section{LOCALIZAÇÃO DA ÁREA DE ESTUDO}

A área de estudo localiza-se na RPPN Pousada das Araras a qual denominaremos como Pousada das Araras no restante do trabalho, possui uma área de 175 ha, e se encontra a $40 \mathrm{~km}$ da cidade de Serranópolis-GO, no Sudoeste Goiano, a cerca de 450 km da capital Goiânia, com as coordenadas UTM 393493 (E) e 7959379 (N), (Mapa 1). 


\section{Metodologia aplicada na escala topoclimática da Pousada das Araras}

A escala topoclimática foi introduzida por Thorntwaite em (1953) apud Smith (1975), no sentido de ampliar a significância do gradiente horizontal da variação dos elementos climáticos. A escala topoclimática corresponde a uma derivação do clima local devido à rugosidade do terreno, e tem como consequência a energização diferenciada do terreno, durante o período diurno, para as diversas faces de exposição à radiação solar (RIBEIRO, 1993).

Na escala topoclimática buscou-se entender as características do relevo da Pousada das Araras, verificando as relações existentes entre temperatura do ar com a topografia, durante o período de amostragem entre os meses de maio de 2010 e março de 2011.

Para analisar gradiente térmico e higrométrico foi traçado um perfil topográfico da Pousada das Araras, utilizando dados de temperatura e umidade relativa do ar utilizando cinco termohigrômetros, (nos pontos P1 ao P5) situados ao longo da trilha da Pousada, entre cotas altimétricas de $543 \mathrm{~m}$ (cota inferior) a $619 \mathrm{~m}$ (cota superior) como pode ser observado no Mapa 2.

Mapa 1 - Localização da área de estudo.

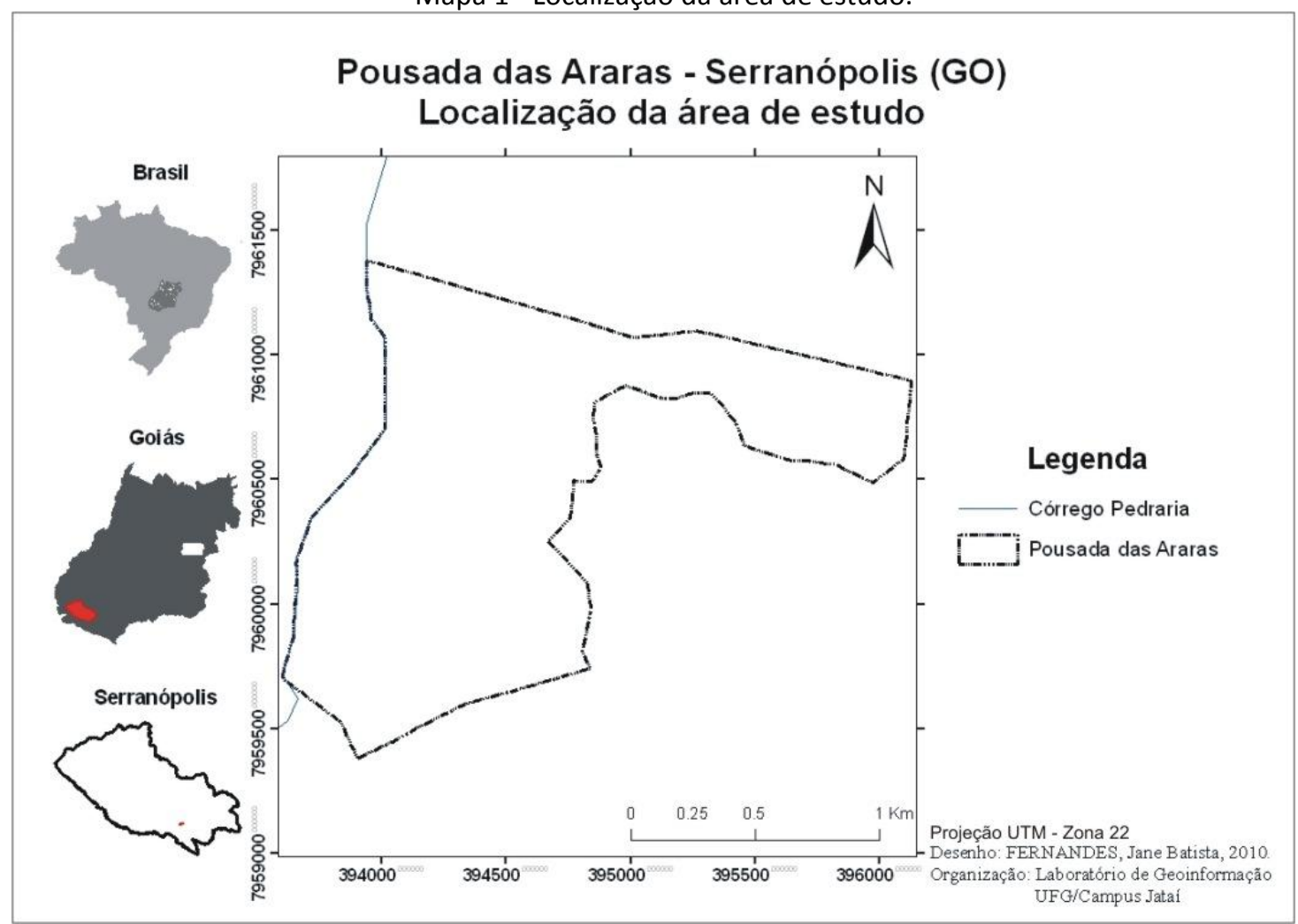

Fonte: Lopes, R.M. (2010). 
De acordo com Ayoade (2007, p. 53) "o relevo tem um efeito atenuador sobre a temperatura, principalmente porque a temperatura do ar normalmente diminui com a altitude crescente a uma taxa média de $0,65 \circ \mathrm{C}$, a cada 100 metros".

Sobre essa taxa no resfriamento da temperatura, os autores Mendonça e Dani-Oliveira (2007, p. 57) confirmam e ressaltam, porém, que "existem situações que provocam uma inversão térmica, isto é, ao invés de resfriar-se com a altitude, o ar passa a se aquecer, invertendo o perfil da curva de temperatura".

Para verificar a taxa do gradiente térmico e a existência da inversão térmica na Pousada das Araras, em função da altitude e das características fisionômicas, especificamente cobertura vegetal e rochedo utilizaram-se técnicas estatísticas, como a correlação $\left(R^{2}\right)$ que expressa a relação entre duas ou mais variáveis, ao nível de $5 \%$ de probabilidade.

Mapa 2 - Localização dos pontos de coletas, na área da Pousada das Araras Serranópolis-GO.

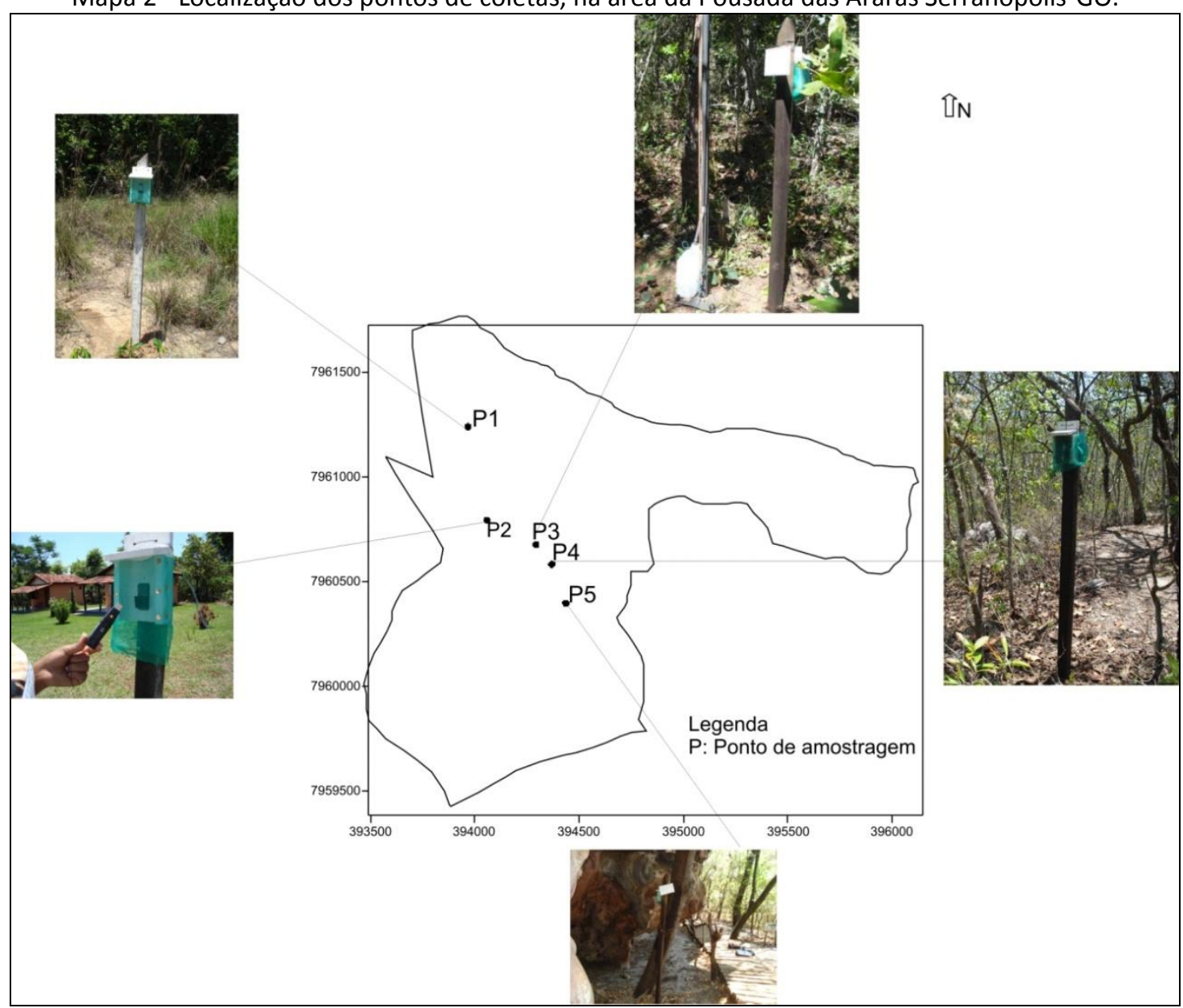

Fonte: Lopes, R.M. (2010). 


\section{Aspectos topoclimáticos da Pousada das Araras}

Hipsometria, declividade, exposição das vertentes da Pousada das Araras

Os fatores denominados de topoclimáticos são aqueles que dependem do relevo local, especialmente da configuração do terreno e da exposição desse em relação à radiação solar. Refere-se ao fenômeno em escala local, em que a topografia condiciona o topoclima, devido às condições do relevo local: exposição e configuração do terreno (PEREIRA et al, 2002). Na escala topoclimática a altitude é um dos principais elementos, para analisar a variação da temperatura com a altitude (MENDONÇA e DANI-OLIVEIRA 2007, p. 57).

A altimetria da Pousada das Araras varia, entre as cotas altimétricas de 543 a $630 \mathrm{~m}$, entre os pontos $\mathrm{P} 1$ ao $\mathrm{P} 5$, com uma variação de $76 \mathrm{~m}$ (Desenho 1).

De acordo com as cotas altimétricas dos pontos de coleta, Mapa 3, procurou-se representar as áreas mais elevadas das mais baixas, porque geralmente as áreas mais elevadas são mais frias e as mais baixas quentes, ou seja, quando ocorre a inversão térmica essa situação pode se inverter.

Desenho 1 - Perfil altimétrico com indicação dos pontos da trilha da Pousada das Araras.

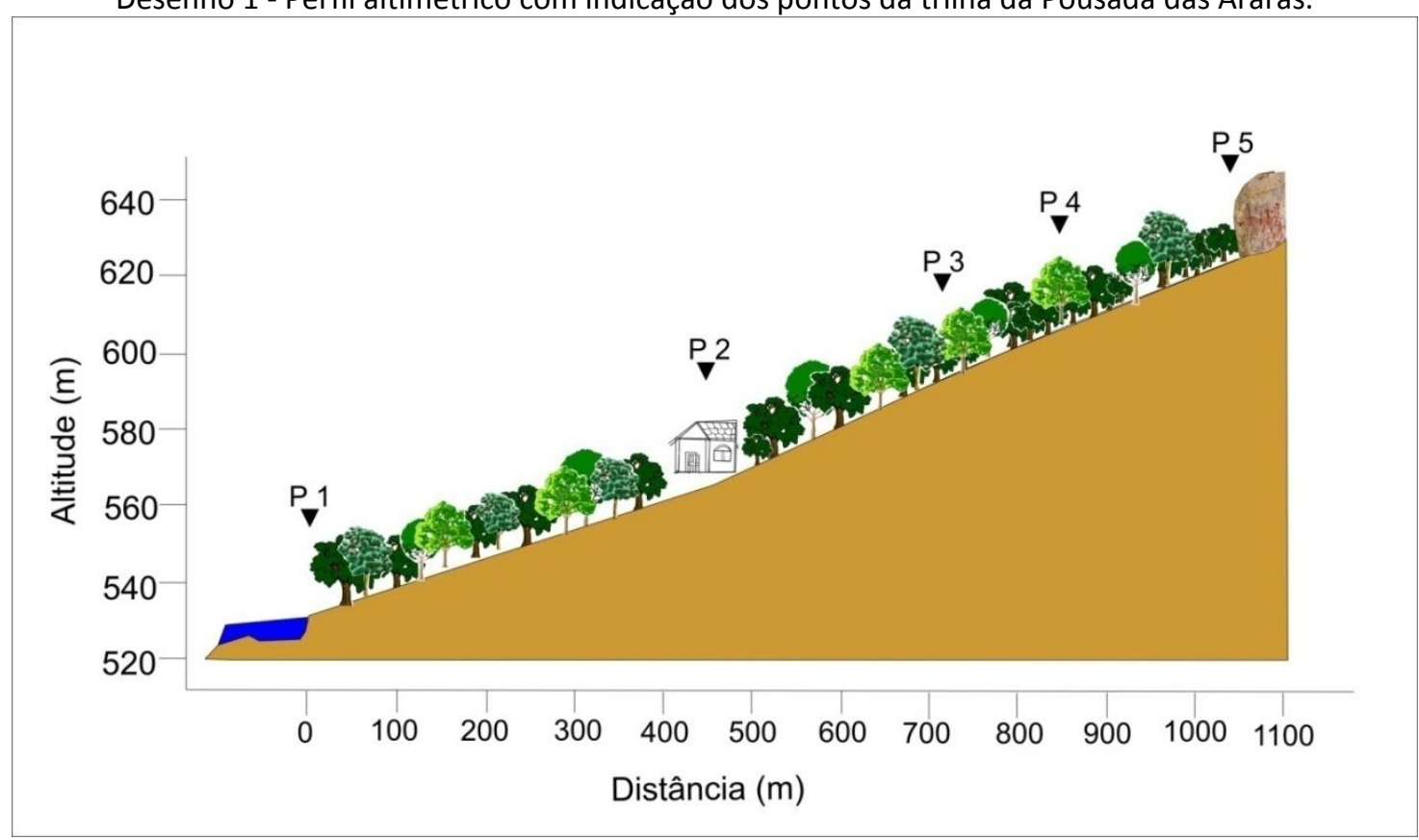

Fonte: LOPES, R.M. (2011). Organização: ROCHA J. R. (2011). 
Mapa 3 - Hipsometria da Pousada das Araras Serranópolis-GO.

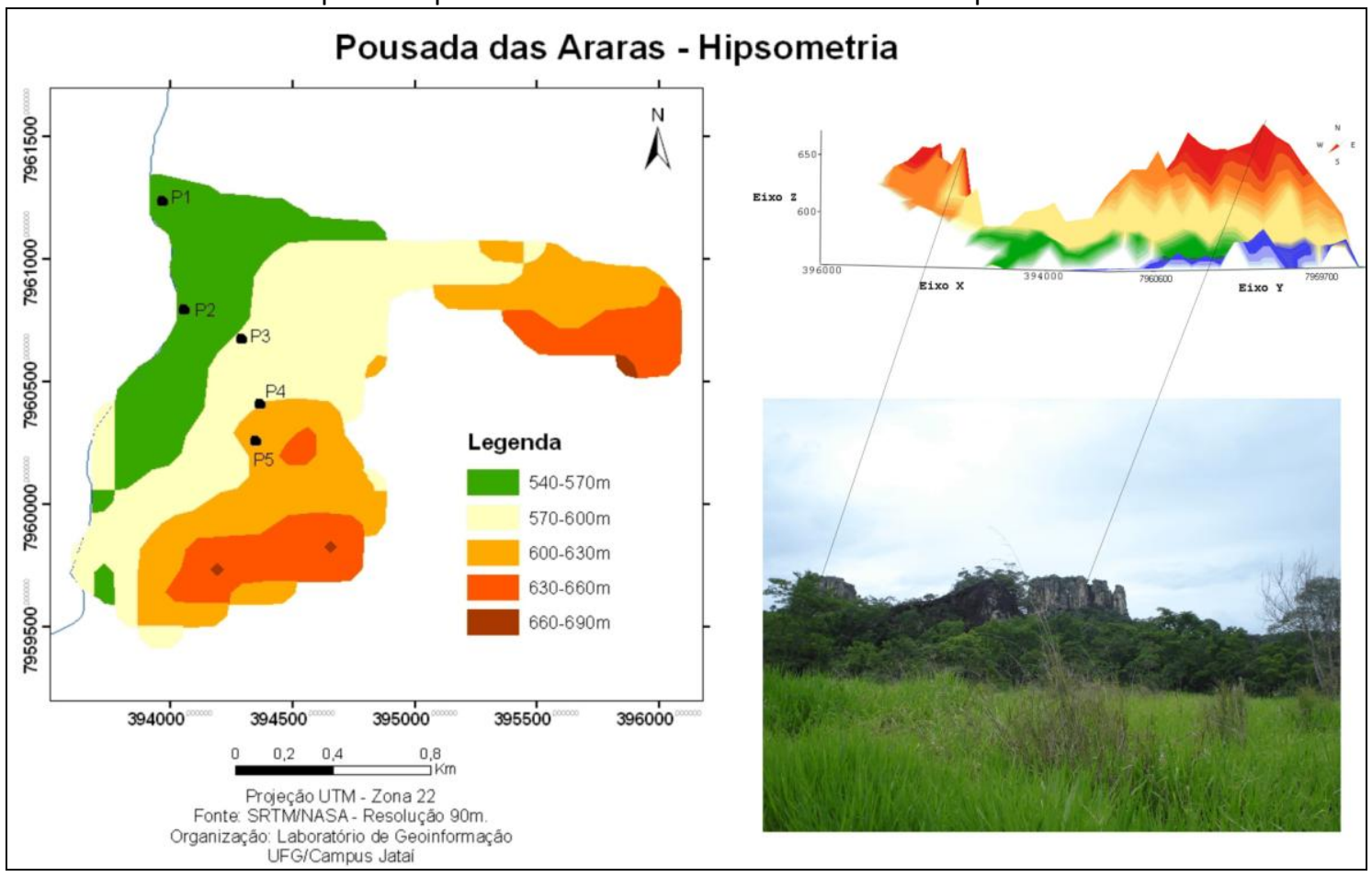

Fonte: LOPES, R.M. (2011).

De acordo com Mendonça e Oliveira (2007, pág. 41), “o relevo apresenta três atributos importantes na definição dos climas: posição, orientação de suas vertentes e declividade". Neste sentido, a posição do relevo da Pousada das Araras, "vai favorecer ou dificultar os fluxos de calor e umidade", e a orientação do relevo em relação ao sol irá definir as vertentes mais aquecidas e mais secas, frias e úmidas.

Os pontos P1 e P2 estão localizados em cotas altimétricas mais baixa, compreende o fundo de vale do córrego Pedraria, que situa no limite de área da Pousada, enquanto que o P4 e P5 estão localizados em altitudes maiores.

As características do relevo, como a declividade podem influenciar na radiação incidente na superfície, na Pousada das Araras verificou que predominam declividades que variam entre 0 a $30 \%$, sendo que os pontos P4 e P5 possui maiores declividades entre 20 a 30\% (Mapa 4). 


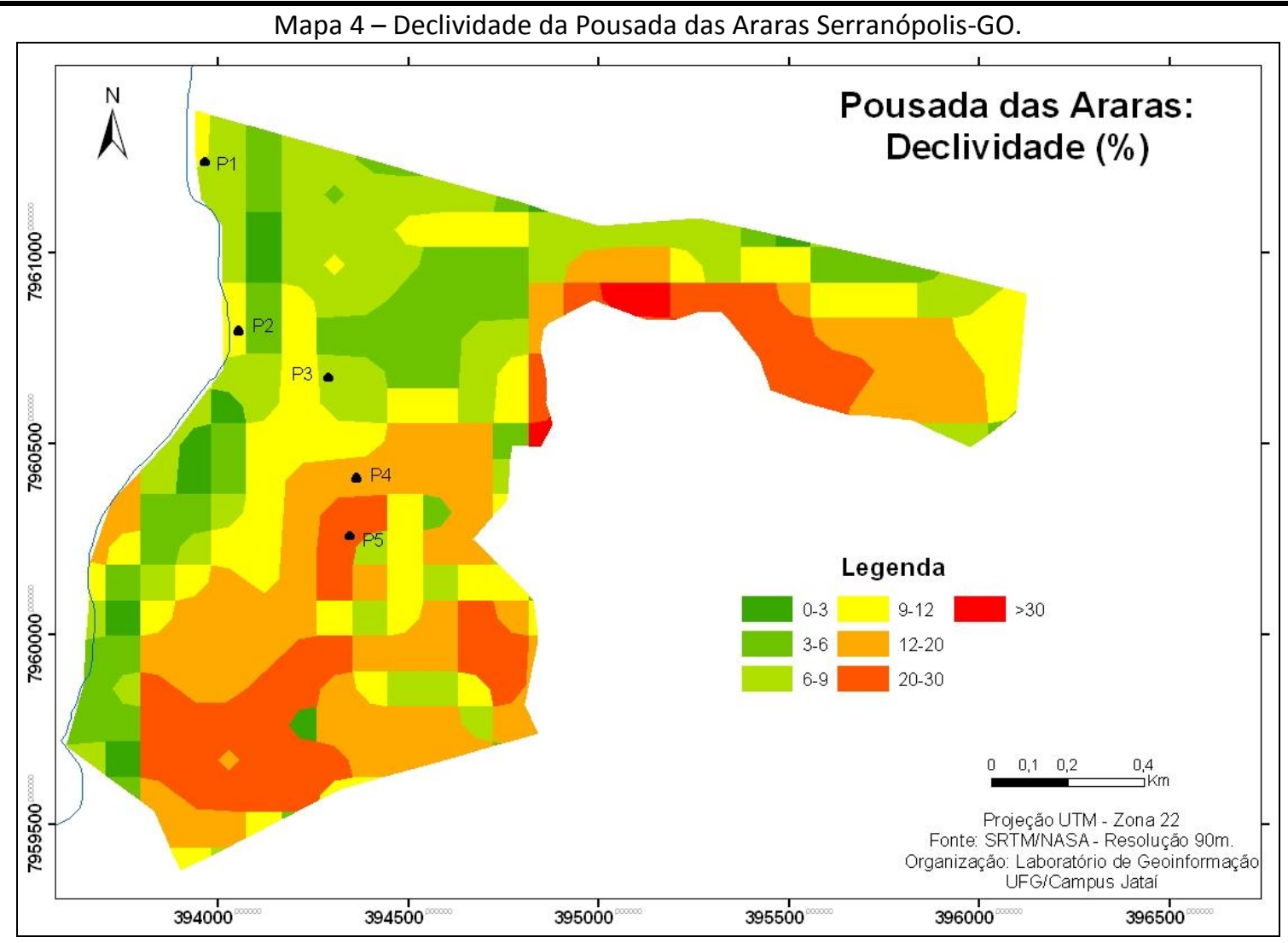

Fonte: LOPES, R.M. (2011).

A partir da análise topoclimática, verificou-se que a temperatura do ar do no P5 apresenta relação com a altitude no horário das $15 \mathrm{~h}$, ou seja, nos demais horários analisados, outros fatores como por exemplo, a vegetação no P4 e o paredão de rocha no P5 influenciaram na variabilidade da temperatura do ar, e não necessariamente a altitude (Mapa 3).

A declividade, a exposição, a orientação e a elevação das ondulações, devem ser consideradas no estudo da topografia de uma determinada área, sendo que até as insignificantes alterações de elevação e de orientação podem causar modificações relevantes em locais situados a pequena distância um do outro.

Nota-se que a exposição das vertentes contribuiu para que os raios solares repercutissem evidentemente na temperatura ar nos pontos P3, P4 e P5 localizados entre a vertente voltada para oeste, constatou-se que no período diurno recebe maior influência dos raios solares, consequentemente, apresentará diferença nos valores de temperatura entre uma vertente orientada ao Norte apresenta-se mais quente.

A exposição do terreno influência diretamente na variabilidade dos elementos climáticos analisados, ou seja, na área da Pousada das Araras, os raios solares incidem mais diretamente sobre as faces voltadas para o Norte, onde localizam os pontos P1, P2 e consequentemente, 
transmitem maior quantidade de calor para esta vertente em relação a outras exposições (Mapa 5).

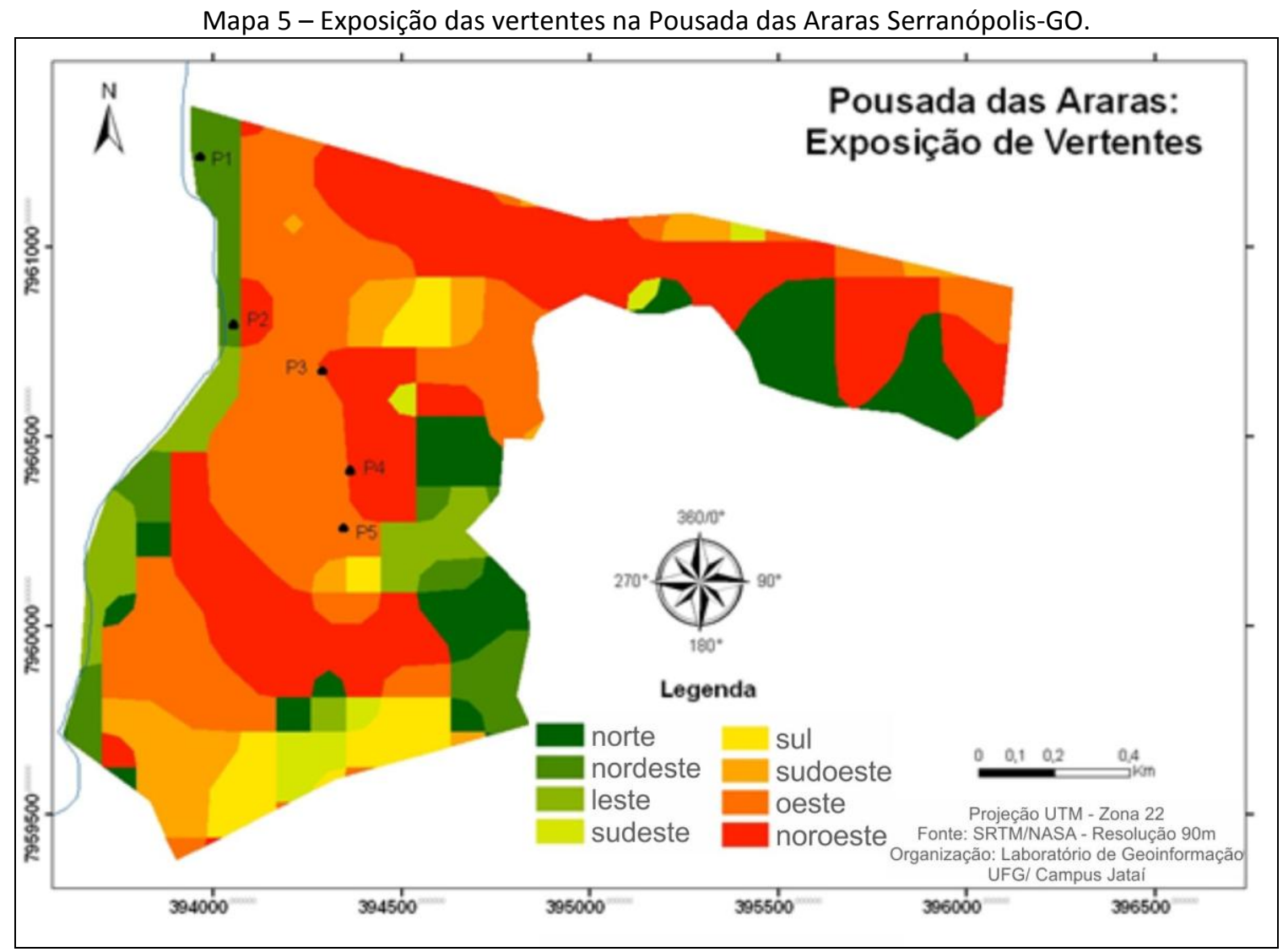

Fonte: LOPES, R.M. (2011).

\section{Relação entre temperatura média do ar e a altitude na Pousada das Araras, nos horários}

15 e $21 h$

Verificou-se às $15 \mathrm{~h}$, que a temperatura média do ar, dos pontos $\mathrm{P} 1$ ao $\mathrm{P} 5$ oscilou de 24,2 a $32,5^{\circ} \mathrm{C}$, sendo que o maior valor $32,5^{\circ} \mathrm{C}$ foi registrado no P1 e o menor valor ocorreu no P5. A regressão linear apresentou gradiente térmico de $-0,091$, e o coeficiente de correlação $\left(R^{2}\right)$ foi de 0,800 , valor que explica que, às $15 \mathrm{~h}$, a temperatura diminui com a altitude, numa correlação de $80 \%$, confirmando que a temperatura diminuiu com a altitude (Gráfico 1). 
Gráfico 1 - Relação da temperatura média do ar e a altitude às 15h e 21h, no mês de maio de 2010, na Pousada das Araras Serranópolis-GO.

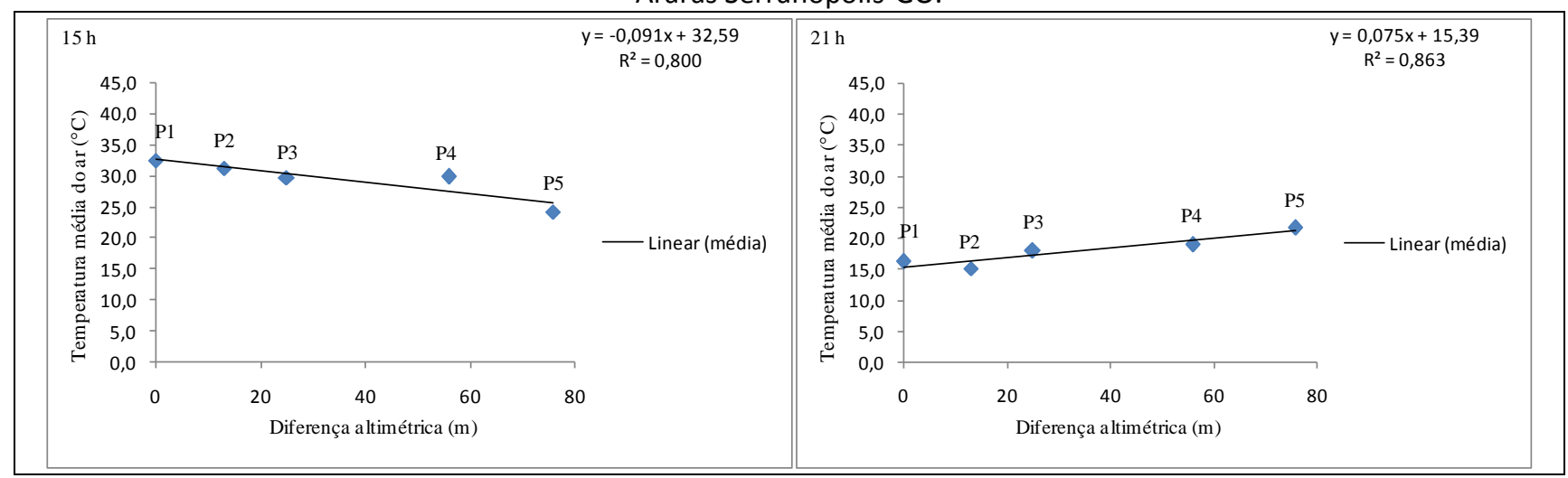

Fonte: LOPES, R.M. (2011).

Às $21 \mathrm{~h}$, o comportamento da temperatura média do ar, dos pontos $\mathrm{P} 1$ ao $\mathrm{P} 5$, oscilou de 15,1 a $21,6^{\circ} \mathrm{C}$. A menor média de temperatura, $15,1^{\circ} \mathrm{C}$, foi registrada no $\mathrm{P} 2$, na sede da Pousada das Araras, e a maior média, $21,6^{\circ} \mathrm{C}$, ocorreu no P5. Este horário mostra que as características de uso de terra (sede, gramineas e Cerrado aberto), influenciam na diminuição da temperatura com altitude. O P2, na Sede, perdeu calor devido às atividades de uso da terra e o P5 por estar localizado próximo ao paredão rochoso, conservou o calor.

De acordo o gráfico de regressão linear, às $21 \mathrm{~h}$, o valor médio de temperatura do ar, apresentou uma correlação $\left(R^{2}\right)$ com a altitude, de 0,863 , ou $86 \%$, ou seja, é extremamente significativa e o gradiente térmico foi de 0,075 de aumento dos pontos P1 ao P5 (Gráfico 1).

Às $15 \mathrm{~h}$, a temperatura média do ar oscilou de 24,3 a $35,2^{\circ} \mathrm{C}$, sendo que a menor média, $24,3^{\circ} \mathrm{C}$, foi registrada no $\mathrm{P} 5$, localizado na cota altimétrica mais elevada, $619 \mathrm{~m}$. Já a maior média, $35,2^{\circ} \mathrm{C}$, ocorreu no P1, na cota altimétrica mais baixa, $543 \mathrm{~m}$. O gradiente térmico vertical apresentou-se negativo, $-0,110$, e o coeficiente de correlação foi de 0,650 , ou seja, de aproximadamente $65 \%$, o que é significativo frente ao efeito da diminuição da temperatura com altitude (Gráfico 2).

Às $21 \mathrm{~h}$, a temperatura média do ar entre os pontos P1 e P5 oscilou de 15,3 a $23,1^{\circ} \mathrm{C}$, a menor média de temperatura, $15,3^{\circ} \mathrm{C}$, foi registrada no $\mathrm{P} 1$, sendo que a maior média, $23,1^{\circ} \mathrm{C}$, ocorreu no P5. O gradiente térmico vertical apresentou-se positivo, de 0,108, com um coeficiente de correlação de $94 \%$ em relação à temperatura do ar e a variação da altitude, devido ao paredão de rocha (Gráfico 2). 
Gráfico 2 - Relação da temperatura média do ar e a altitude às 15 e 21h, no mês de junho de 2010, na Pousada das Araras Serranópolis-GO.

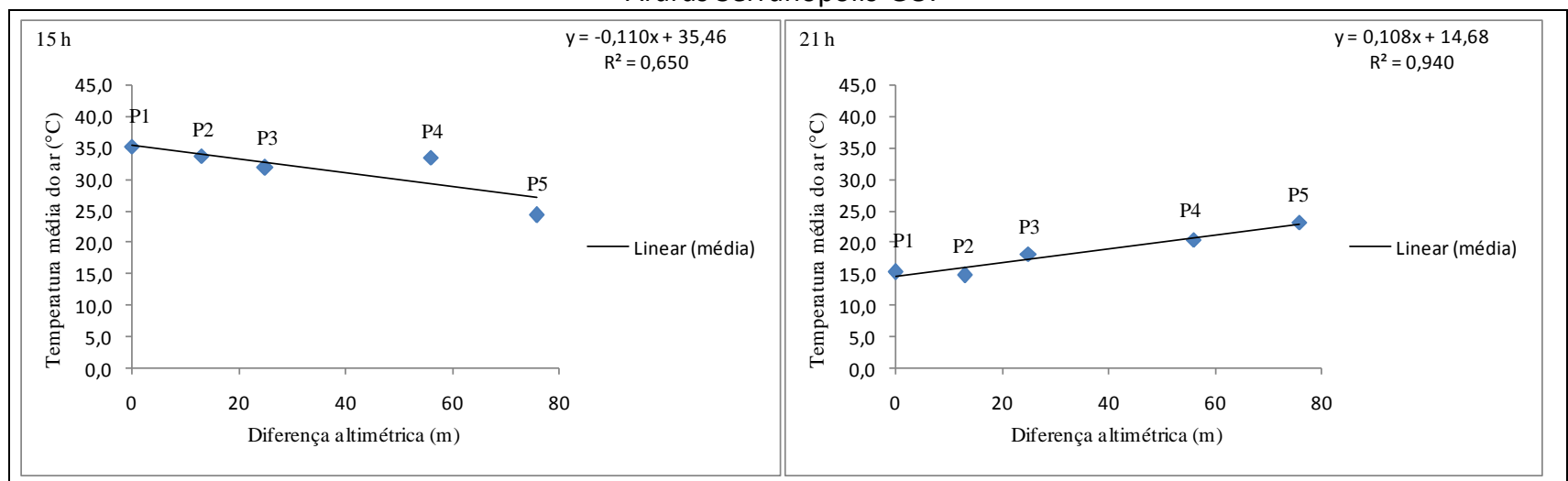

Fonte: LOPES, R.M. (2011).

A temperatura média do ar, no mês de julho, no horário das $15 \mathrm{~h}$, oscilou de 25,7 a $35,8^{\circ} \mathrm{C}$. Neste horário, a maior média, $35,8^{\circ} \mathrm{C}$ ocorreu no P1. A menor média, durante o mês, foi registrada no P5. O gradiente vertical da temperatura média entre os pontos foi negativo $-0,089$, e o índice de correlação apresentou-se em 48\% entre a temperatura e altitude (Gráfico 3).

Gráfico 3 - Relação da temperatura média do ar e a altitude às 15 e 21h, no mês de julho de 2010, na Pousada das Araras Serranópolis-GO

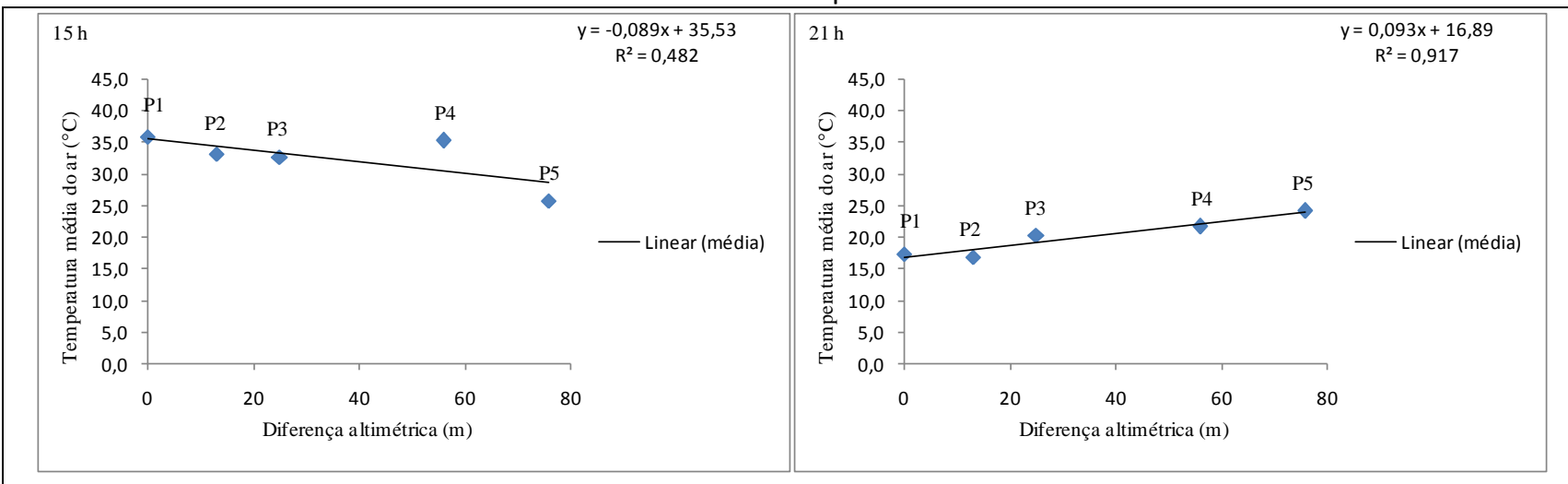

Fonte: LOPES, R.M. (2011).

Às $21 \mathrm{~h}$ do mês de julho, a temperatura média do ar dos pontos $\mathrm{P} 1$ ao $\mathrm{P} 5$ oscilou de 17,3 a $24,1^{\circ} \mathrm{C}$. A menor média de temperatura, $17,3^{\circ} \mathrm{C}$, foi registrada no $\mathrm{P} 1$, e a maior média, $24,1^{\circ} \mathrm{C}$, ocorreu no P5. O gradiente térmico vertical da média da temperatura foi positivo, de 0,917, e, estatisticamente, apresentou-se com uma correlação de $91 \%$ neste horário. A média da temperatura do ar está relacionada com a variação da altitude, pois o rochedo conservou a temperatura adquirida durante o dia (Gráfico 3).

A temperatura média do ar, durante o mês de agosto, no horário das $15 \mathrm{~h}$, oscilou de 27,1 a $38,8^{\circ} \mathrm{C}$. Neste horário, a maior média, $38,8^{\circ} \mathrm{C}$ ocorreu no $\mathrm{P} 1$ e a menor média, $27,1^{\circ} \mathrm{C}$ foi registrada 
no P5. O gradiente vertical da temperatura média entre os pontos foi negativo, $-0,127$, o que indica que a temperatura diminuiu com altitude. A correlação foi significativa, de 87\% (Gráfico 4).

Gráfico 4- Relação da temperatura média do ar e a altitude às 15 e 21h, no mês de agosto de 2010, na Pousada das Araras Serranópolis-GO.

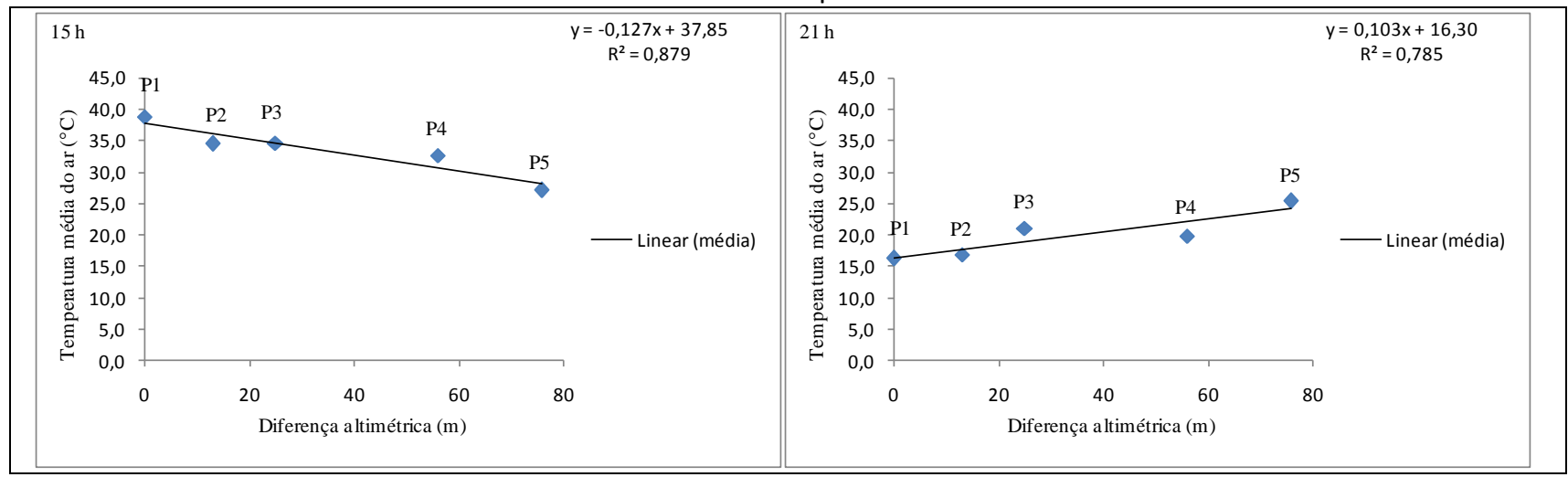

Fonte: LOPES, R.M. (2011).

Às $21 \mathrm{~h}$ do mês de agosto, a temperatura média do ar, entre os pontos $\mathrm{P} 1$ ao $\mathrm{P} 5$, oscilou de 16,2 a $25,3^{\circ} \mathrm{C}$. A menor média de temperatura, $16,2^{\circ} \mathrm{C}$, foi registrada no $\mathrm{P} 1$, sendo que a maior média, $25,3^{\circ} \mathrm{C}$, ocorreu no $\mathrm{P} 5$. O gradiente térmico vertical da média da temperatura para as $21 \mathrm{~h}$ foi positivo, 0,103 , e a correlação ficou em $78 \%$, entre a média da temperatura do ar e a altitude (Gráfico 4).

Às $15 \mathrm{~h}$ em setembro, a média da temperatura do ar, entre os pontos $\mathrm{P} 1$ e P5, oscilou entre 29,8 a 39,1 으, sendo que a menor média ocorreu no P5. O maior valor foi registrado no P4, de 39,1 으. $\mathrm{O}$ gradiente térmico apresentou-se negativo, de -0,073, e o coeficiente de correlação ficou em $37 \%$ entre a média da temperatura ar com a altitude, (Gráfico 5).

Gráfico 5 - Relação da temperatura média do ar e a altitude às 15 e 21h, no mês de setembro de 2010, na Pousada das Araras Serranópolis-GO.

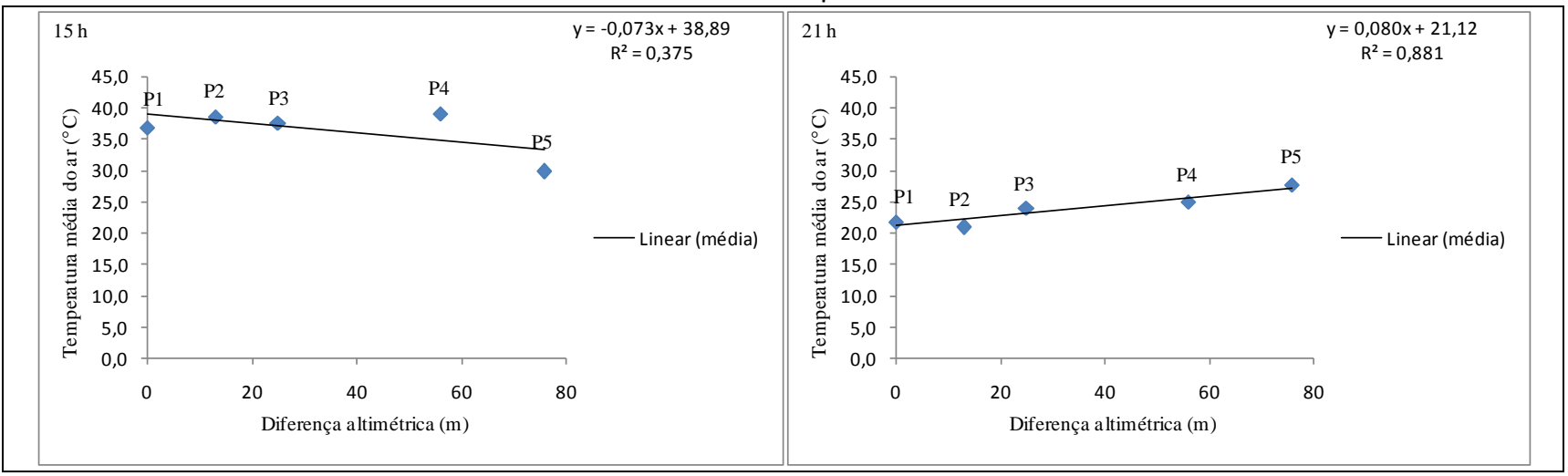

Fonte: LOPES, R.M. (2011). 
No horário das $21 \mathrm{~h}$, a temperatura média do ar dos pontos $\mathrm{P} 1$ ao $\mathrm{P} 5$ oscilou de 20,9 a $27,6^{\circ} \mathrm{C}$, e a menor média de temperatura, $20,9^{\circ} \mathrm{C}$, foi registrada no P2. A maior média, $27,6,{ }^{\circ} \mathrm{C}$, por sua vez, ocorreu no P5. O gradiente térmico vertical da média da temperatura, para as $21 \mathrm{~h}$, foi positivo, de 0,080 , o coeficiente de correlação $\left(R^{2}\right)$ de $88 \%$ indica que às $21 \mathrm{~h}$, a média da temperatura do ar está relacionada com a variação da altitude do perfil topográfico da Pousada das Araras (Gráfico 5).

A temperatura média em outubro, às $15 \mathrm{~h}$, oscilou entre 27,8 e $34,8^{\circ} \mathrm{C}$, neste horário a maior média de $34,8^{\circ} \mathrm{C}$ ocorreu no $\mathrm{P} 1$, sendo que a menor média foi registrada no $\mathrm{P} 5$. $\mathrm{O}$ gradiente vertical foi negativo, $-0,067$, e o índice de correlação apresentou-se em 0,575. Apenas $57 \%$ da variabilidade da temperatura do ar relaciona com a altitude do perfil topográfico da Pousada das Araras (Gráfico 6).

Gráfico 6 - Relação da temperatura média do ar e a altitude às 15 e 21h, no mês de outubro de 2010, na Pousada das Araras Serranópolis-GO.

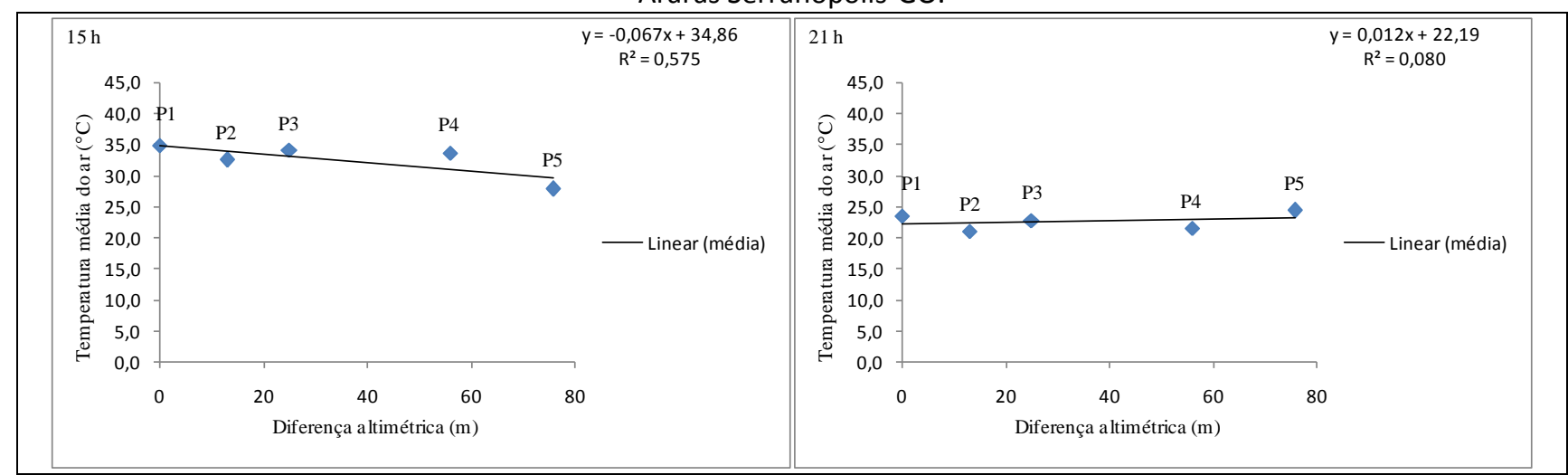

Fonte: LOPES, R.M. (2011).

Às $21 \mathrm{~h}$, a temperatura média do ar entre os pontos $\mathrm{P} 1$ ao $\mathrm{P} 5$ oscilou de 21 a $24,3^{\circ} \mathrm{C}$, e a menor média foi registrada no $\mathrm{P} 2$ com 21,0 ㅇ․ A maior média, $24,3^{\circ} \mathrm{C}$, verificou-se no $\mathrm{P} 5$. $\mathrm{O}$ gradiente térmico vertical da média da temperatura foi positivo, de 0,012, e o coeficiente de correlação, de 0,080, indicando a correlação de $80 \%$ entre média da temperatura do ar e altitude (Gráfico 6). A temperatura média do ar, no mês de novembro, no horário das $15 \mathrm{~h}$, oscilou entre 27,6 e $35,9^{\circ} \mathrm{C}$. Neste horário, a maior média ocorreu no $\mathrm{P} 1$, de $35,9^{\circ} \mathrm{C}$. O P5 registrou a menor média $27,7^{\circ} \mathrm{C}$. $\mathrm{O}$ gradiente vertical da temperatura foi negativo, $-0,100$, e o índice de correlação, 0,820, apresentou uma correlação significativa, ou seja, $82 \%$ da variabilidade da temperatura do ar com a altitude, (Gráfico 7). 
Gráfico 7 - Relação da temperatura média do ar e a altitude às 15 e 21h, no mês de novembro de 2010, na Pousada das Araras Serranópolis-GO.

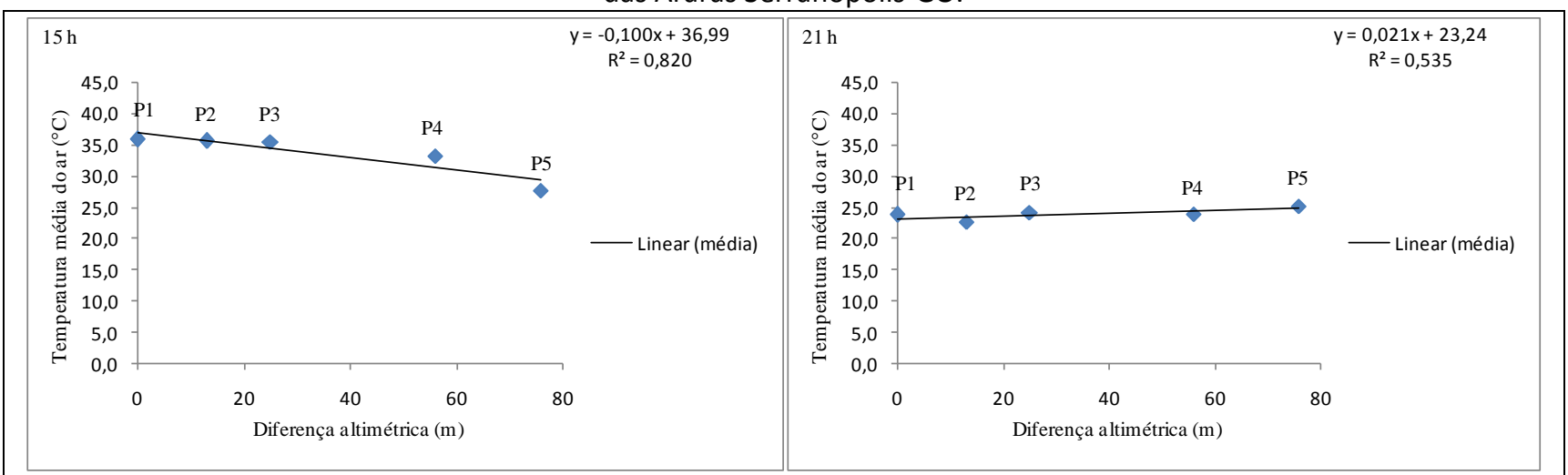

Fonte: LOPES, R.M. (2011).

Às $21 \mathrm{~h}$ do mês de novembro, a variabilidade da temperatura média do ar entre os pontos P1 e P5 variou de 22,6 a $25,2^{\circ} \mathrm{C}$. A menor média de temperatura, $22,6^{\circ} \mathrm{C}$, foi registrada no $\mathrm{P} 2$, e a maior média, $25,2^{\circ} \mathrm{C}$, no $\mathrm{P} 5$. $\mathrm{O}$ gradiente térmico vertical da média foi positivo, de 0,021 , e o coeficiente de correlação de 0,535 indica que durante o período analisado a correlação foi 53\% (Gráfico 7).

No mês de dezembro registrou às $15 \mathrm{~h}$ a temperatura média entre 26,6 a $34,4^{\circ} \mathrm{C}$. A menor média foi de $26,6^{\circ} \mathrm{C}$ no $\mathrm{P} 5$ e a maior de $34,6^{\circ} \mathrm{C}$, no $\mathrm{P} 2$, sede da Pousada das Araras. O gradiente térmico, às 15 h, apresentou-se negativo, $-0,094$, e o coeficiente de correlação $\left(R^{2}\right)$ foi de 0,876 , o que indica uma boa correlação entre a variação da temperatura com a altitude, (Gráfico 8).

No horário das 21 horas a temperatura média do ar oscilou entre 22,9 e $24,8^{\circ} \mathrm{C}$, às $21 \mathrm{~h}$ em que a menor média foi de $22,9^{\circ} \mathrm{C}$ no $\mathrm{P} 2$, enquanto a maior média, $24,8^{\circ} \mathrm{C}$ aconteceu no $\mathrm{P} 5$. A regressão linear no gradiente térmico positivo foi de 0,015 e o coeficiente de correlação $\left(R^{2}\right)$ foi de $44 \%$, (Gráfico 8).

Gráfico 8 - Relação da temperatura média do ar e a altitude às 15 e 21h, no mês de dezembro de 2010, na Pousada das Araras Serranópolis-GO.

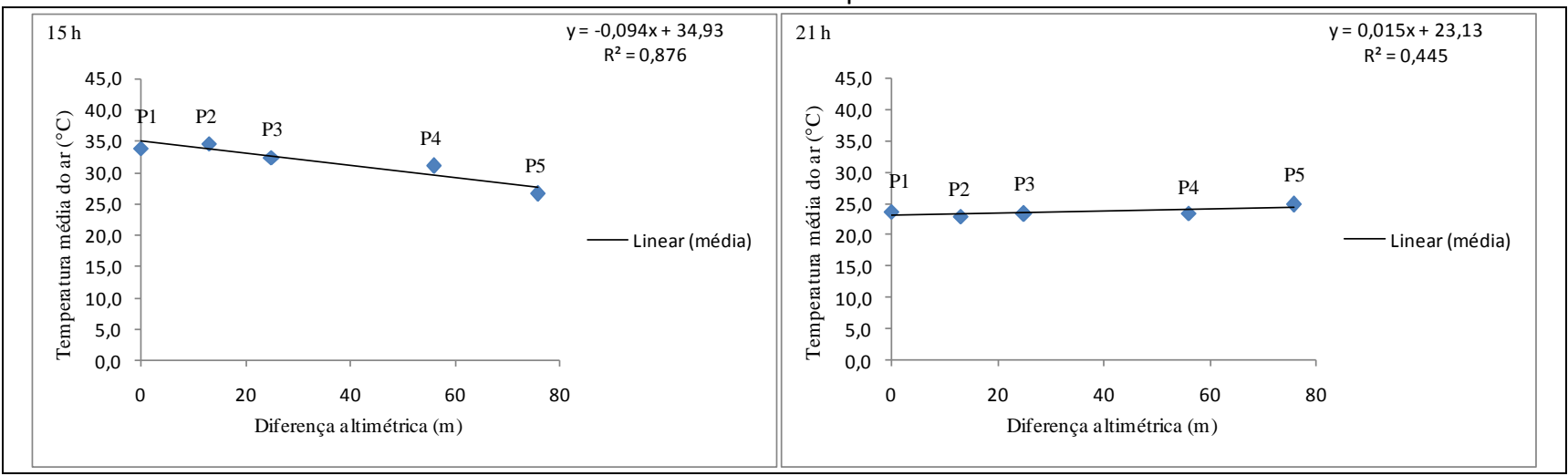

Fonte: LOPES, R.M. (2011). 
Às $15 \mathrm{~h}$, no mês de janeiro, a temperatura média do ar oscilou entre 26,9 e $36^{\circ} \mathrm{C}$, a menor média de $26,9^{\circ} \mathrm{C}$ ocorreu no $\mathrm{P} 5$ e a maior média foi de $36^{\circ} \mathrm{C}$ no $\mathrm{P} 2$. O gradiente térmico foi negativo, 0,0112, e o coeficiente de correlação $\left(R^{2}\right)$ foi de $90 \%$, (Gráfico 9).

Gráfico 9 - Relação da temperatura média do ar e a altitude às 15 e 21h, no mês de janeiro de 2011, na Pousada das Araras Serranópolis-GO.

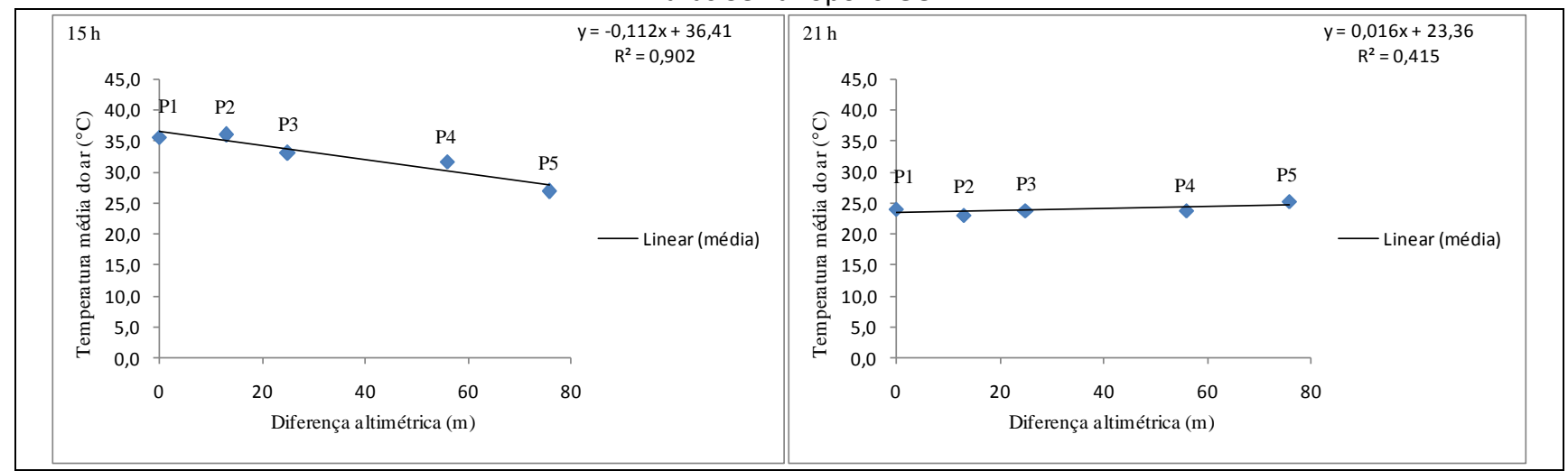

Fonte: LOPES, R.M. (2011).

Às $21 \mathrm{~h}$, a temperatura média do ar variou entre $23,0^{\circ} \mathrm{C}$ e $25,2^{\circ} \mathrm{C}$. A menor média foi $23,0^{\circ} \mathrm{C}$, registrada no $\mathrm{P} 2$. E a maior média foi de $25,2^{\circ} \mathrm{C}$ no $\mathrm{P} 5$. $\mathrm{O}$ gradiente térmico foi positivo, de 0,016 , e o coeficiente de correlação $\left(R^{2}\right)$ foi de $41 \%$, (Gráfico 9).

Às $15 \mathrm{~h}$, em fevereiro a temperatura média oscilou entre 26,6 e $35,3^{\circ} \mathrm{C}$, a menor média, $26,6^{\circ} \mathrm{C}$ ocorreu no P5 e a maior, de $35,3^{\circ} \mathrm{C}$ confirmou-se no P1. A regressão linear para as $15 \mathrm{~h}$ indicou o gradiente térmico negativo de $-0,113$ e o coeficiente de correlação $\left(R^{2}\right)$ apresentou-se com o valor de $95 \%$ entre a altitude e a temperatura do ar, (Gráfico 10).

Gráfico 10 - Relação da temperatura média do ar e a altitude às 15 e 21h, no mês de fevereiro de 2011, na Pousada das Araras Serranópolis-GO.

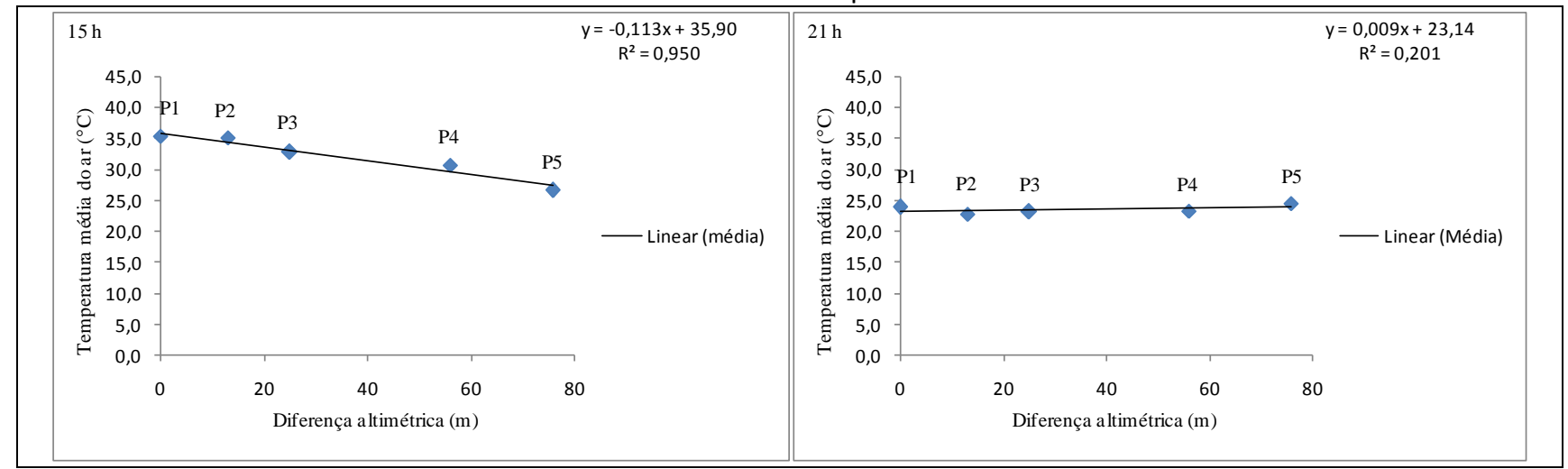

Fonte: LOPES, R.M. (2011). 
Às $21 \mathrm{~h}$, a temperatura média do ar variou entre 22,7 e $24,4^{\circ} \mathrm{C}$. Neste horário, a menor média ocorre no P2 e a maior média no P5. O gradiente térmico foi negativo, -0,009, e o coeficiente de correlação, $\left(R^{2}\right)$ de $20 \%$, mostra uma fraca correlação entre as variáveis altitude e temperatura do ar (Gráfico 10).

Em março às $15 \mathrm{~h}$, a temperatura média do ar variou $25,0^{\circ} \mathrm{C}$ a $32,4^{\circ} \mathrm{C}$, a menor média foi de $25,0^{\circ} \mathrm{C}$, no $\mathrm{P} 5$, e a maior foi de $32,4^{\circ} \mathrm{C}$, que ocorreu no $\mathrm{P} 2$, localizado na sede. A regressão linear entre os pontos P1 e P5 apresentou o gradiente térmico negativo de -0,091, e o coeficiente de correlação foi de $\left(R^{2}\right) 92 \%$ entre a altitude e a temperatura do ar (gráfico 11 ).

Gráfico 11 - Relação da temperatura média do ar e a altitude às 15 e 21h, no mês de março de 2011, na Pousada das Araras Serranópolis-GO.

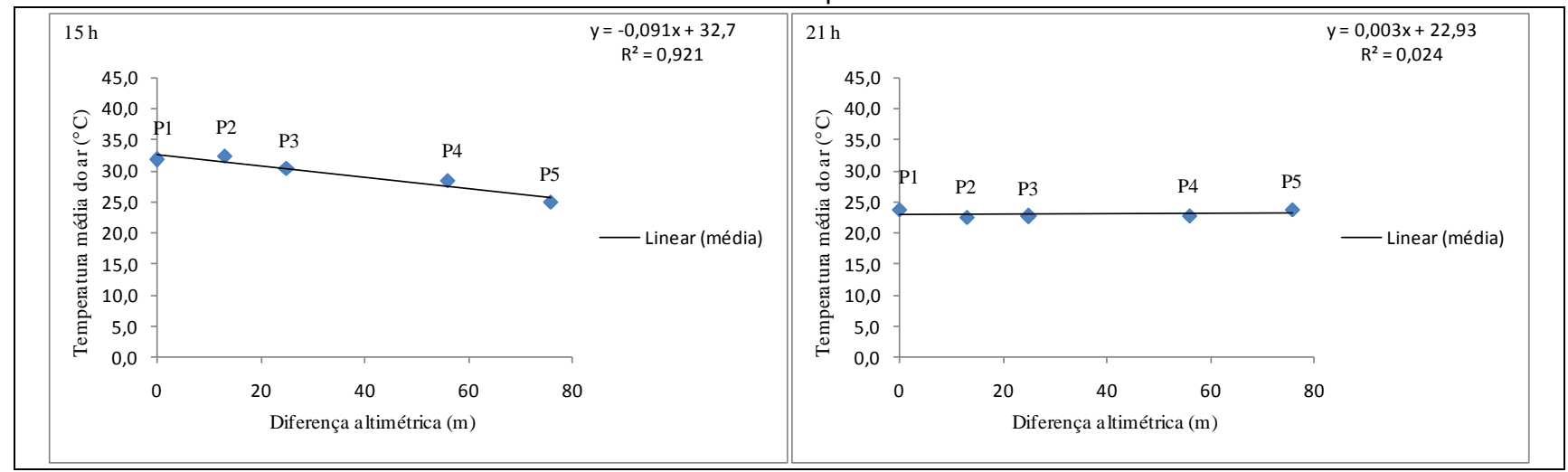

Fonte: LOPES, R.M. (2011).

Às $21 \mathrm{~h}$, a temperatura média do ar variou $22,5^{\circ} \mathrm{C}$ e $23,7^{\circ} \mathrm{C}$, a menor média ocorreu no $\mathrm{P} 2$, neste mês. P1 e P5 registraram os mesmos valores das médias da temperatura do ar $23,7^{\circ} \mathrm{C}$. O gradiente térmico positivo foi de 0,003 e o coeficiente de correlação $\left(R^{2}\right)$ foi de $2 \%$, o que indica correlação baixa entre as variáveis (Gráfico 11).

\section{CONSIDERAÇÕES FINAIS}

Com base nos resultados na escala local, topoclimática considera-se que:

a) A variação da temperatura média oscilou entre 19,7 a $25,6 \circ \mathrm{C}$, na escala topoclimática. Constatou-se que às $15 \mathrm{~h}$, a correlação foi acima dos $80 \%$, e às $21 \mathrm{~h}$ ocorreu a inversão térmica entre os pontos P1 e P5, o que justifica essa correlação e a inverão térmica pelas características pontuais que cada ponto apresenta, como, solo, vegetação, paredão de rocha, próximidade do córrego. A variação da temperatura do ar mostra que as características de uso da terra modificou a marcha de diminuição da temperatura com 
altitude. O ponto P2, na Sede, perdeu calor devido as atividades de uso e o ponto P5, o paredão rochoso, conservou o calor.

b) Em relação à exposição da vertente, na área da Pousada das Araras, os raios solares incidem em maior proporção sobre as faces voltadas para o Norte, onde localiza o ponto $\mathrm{P} 1$ e $\mathrm{P} 2$, que consequentemente, transmitem maior quantidade de calor para esta vertente em relação a outras exposições.

c) A declividade influencia na radiação incidente na superfície, na Pousada das Araras verificou-se que predominam declividades entre 6 a 9\%, no ponto P1 e 20 e $30 \%$, no ponto P5. Para Mefti et al. (2003), o relevo pode modificar o regime de radiação de acordo com a face de exposição e o grau de inclinação do terreno, promovendo aumento ou diminuição da energia disponível para a biossíntese, podendo ocorrer alterações no balanço de energia e, consequentemente, no microclima local.

d) A fisionomia da vegetação contribui para a quantidade de energia no ambiente, principalmente nos pontos que possuem dossel aberto P1 e P5, no período de estiagem, facilitando a entrada da radiação solar até a superfície acima de $75 \%$, constando que atuação dos fatores físicos como relevo, solo, vegetação, radiação solar e outros contribuem para a variação da temperatura do ar, nos pontos de coleta.

e) Com base nas observações realizadas em campo, verificou-se que existe uma variabilidade da temperatura do ar, precipitação pluvial, na escala local, topo e microclimática, considerando as características fisiográficas de cada ponto de coleta, o que possivelmente influenciou nos valores de temperatura do ar.

\section{REFERÊNCIAS}

AB'SÁBER, A. N.; COSTA JR., M. Contribuição ao estudo do Sudoeste Goiano. Boletim Paulista de Geografia. São Paulo, n. 4, p. 3-26, mar. de 1950.

AYOADE, J.O. Introdução à climatologia para os trópicos. Tradução de Maria Juraci Zani dos Santos, 2 ed. Rio de Janeiro: Bertrand Brasil, 2007. 332p. Revisão de Suely Bastos.

AZEVEDO, T. R.; FUNARI, F. L. Desempenho de registradores digitais de temperatura e umidade do ar em abrigo meteorológico padronizado. GEOUSP Espaço e Tempo: Revista da Pós-Graduação em Geografia, São Paulo, n. 10, 2001, p. 147-164. 
ARMANI, G.; GALVANI, E. Avaliação do desempenho de um abrigo meteorológico de baixo custo. Revista Brasileira de Agrometeorologia, v.13 n.1. Santa Maria, 2005.

ASSUNÇÃO H. F.; SCOPEL I.; SANTOS W. B. Caracterização espacial do clima no município de Jataí. In: CONGRESSO BRASILEIRO DE AGROMETEOROLOGIA, 1999, Florianópolis. Anais..., Florianópolis: Sociedade Brasileira de Agrometeorologia, 1999. Editado em CD-ROM.

EITEN, G. Vegetação do cerrado. In: NOVAES PINTO, M. (Org) Cerrado: caracterização, ocupação e perspectivas. Brasília, ed. Universidade de Brasília, 1999.

FUNATURA - Fundação Pró-Natureza. Plano de manejo reserva natural pousada das araras. Brasília, 1999.

GALVANI, E.; LIMA, N. G. B. A ocorrência inversões térmicas no perfil topoclimático do Pico das Agulhas Negras - RJ. IN: SIMPÓSIO BRASILEIRO DE CLIMATOLOGIA GEOGRÁFICA, 7, 2006. Rondonópolis. Anais... Rondonópolis: UFMT, 2006.

GALVANI, E.; LIMA, N. G. B.; SERAFINI Jr. S.; ALVES, R. R. Avaliação da temperatura do ar no perfil topoclimático do parque estadual de intervales - SP, entre as altitudes de 150 a 950 metros. In: SEMINÁRIO LATINO AMERICANO DE GEOGRAFIA FÍSICA, 4, SEMINÁRIO IBERO-AMERICANO DE GEOGRAFIA FÍSICA, 2008. Santa Maria. Anais... Santa Maria: UFSM, 2008.

GEIGER, R. Manual de microclimatologia: o clima da camada de ar junto ao solo. 4 ed. Lisboa Fundação: Calouste Gulbenkian, 1961, 555p.

GUERRA, A. J. T. Um estudo do meio físico com fins de aplicação ao planejamento do uso agrícola da terra no Sudoeste de Goiás. Rio de Janeiro: IBGE, 1989, 212p.

IBGE, Departamento de Recursos Naturais e Estudos Ambientais, 1989. (Projeto Cerrado II; Convênio IBGE/Embrapa).

LIMA, N. G. B. Análise microclimática dos manguezais da Barra do Ribeira-lguape/SP. 2009.185f. Dissertação de mestrado (Programa de Pós-graduação em Geografia Física) Faculdade de Filosofia, Letras e Ciências Humanas da Universidade de São Paulo.

LOBATO, E. J. V. et al. A. Atlas climatológico do Estado de Goiás. Goiânia: Editora da UFG, 2002. 99p. 
MARIANO, Z. F. A importância da variável climática na produtividade de soja no Sudoeste de Goiás. 2005. 253f. Tese de doutorado (Instituto de Geociências e Ciências Exatas) Campus de Rio Claro. (SP).

MEFTI, A.; BOUROUBI, M. Y.; ADANE, A. Generation of hourly solar radiation for inclined surfaces using monthly mean sunshine duration in Algeria. Energy conversion and Management, v.44, n.19, p.3125-3141, 2003.

MENDONÇA, F.; OLIVEIRA, D. Climatologia: noções básicas e climas do Brasil. São Paulo: Oficina de Textos, 2007.

MONTEIRO, M. B. C. A.; AZEVEdO, T. R. de. Comparação do perfil vertical da Temperatura e da umidade relativa do ar em fragmentos de mata atlântica no Interior e arredores da cidade de são Paulo, SP. Estudos Geográficos, Rio Claro. p. 01-13, dez. 2005.

NIMER, E. Climatologia da região Centro-Oeste. In: Climatologia do Brasil. 2 ed. Rio de Janeiro: IBGE, Departamento de recursos naturais e estudos ambientais, 1989.

RIBEIRO, A. G. As escalas do clima. Boletim de Geografia Teorética. v. 23, n. (45-46), 1993.

SOUZA, L. F. de. Diversidade florística e fenologia reprodutiva em fitofisionomias da Reserva Pousada das Araras (Município de Serranópolis, Estado de Goiás Planalto Central do Brasil). 2009. Tese (Doutorado em Ciências Biológicas) -Instituto de Biociências, Universidade Estadual Paulista Júlio Mesquita Filho, Rio Claro-SP, 2009.

SOUZA, H. A. de. $\mathrm{O}$ desgaste da pintura rupestre e dos abrigos sob rocha na Reserva Particular do Patrimônio Natural (RPPN) Pousada das Araras em Serranópolis-GO: condicionantes naturais. 2005. 75f. Dissertação (Mestrado profissional em Gestão do Patrimônio Cultural) - Instituto Goiano de Pré-História e Antropologia, Universidade Católica de Goiás, Goiânia, 2005.

SCOPEL, I.; MARIANO, Z. F. Tendência de aumento na temperatura do ar no município de JataíGo. In: SIMPÓSIO BRASILEIRO DE CLIMATOLOGIA GEOGRÁFICA, 5, 2002, Curitiba. Anais... Mudanças globais e especificidades climáticas regionais e locais. Curitiba-PR : UFPR, 2002. v. 1. p. 240-243. 
SMITH, K. Principles of applied climatology. London: Megraw, Hill Book Company Ltda., 1975.

ZORTÉA, Marlon. Diversidade e organização de uma taxocenose de morcegos do cerrado

brasileiro. 2002. Tese (Doutorado em Ecologia e Recursos Naturais) Universidade Federal de São Carlos, Brasil, 2002.

Artigo submetido em: 12/03/2014

Artigo aceito em: 08/10/2014 